\title{
Persepsi Mahasiswa Terhadap Pembelajaran Daring pada Matakuliah Praktik Aplikasi Teknologi Informasi
}

\author{
Dwi Ratnawati ${ }^{1}$ Vivianti $^{2}$ \\ ${ }^{1,2}$ Program Studi Pendidikan Teknologi Informasi FHPP UTY \\ 1 dwiratnawati@uty.ac.id* \\ *corresponding author
}

\begin{abstract}
This study aims to find out students' perception toward the implementation of online practicum learning at University of Technology Yogyakarta. This study employs quantitative descriptive method. Perception assessment is carried out by referring to 3 components: the component of teaching learning process, the component of lecturer's ability, as well as the components of facilities and infrastructure. Data collection used is an online questionnaire through Google Form distributed to 168 students who enroll practicum course at University of Technology Yogyakarta using purposive random sampling method. The results show that the components of the teaching learning process obtained a perception level of 79\%, the component of lecturer's ability to obtain a perception level of $82 \%$, and the infrastructures and facilities component obtained a perception level of $80 \%$. Therefore, it can be implied that students' perception toward online practicum course at University of Technology Yogyakarta is positive with a perception rate of $80 \%$.
\end{abstract}

Article Info

\footnotetext{
ABSTRAK

Penelitian ini bertujuan untuk mengetahui persepsi mahasiswa tentang pelaksanaan pembelajaran praktikum secara daring di Universitas Teknologi Yogyakarta. Penelitian ini menggunakan metode deskriptif kuantitatif. Penilaian persepsi dilakukan dengan mengacu pada 3 komponen yaitu: komponen proses belajar mengajar, komponen kemampuan dosen, serta komponen sarana dan prasarana. Pengumpulan data dilakukan dengan menggunakan kuesioner secara daring melalui Google Form kepada 168 mahasiswa yang sedang mengambil mata kuliah praktikum Aplikasi Teknologi Informasi di Universitas Teknologi Yogyakarta dengan menggunakan teknik purposive random sampling. Hasil penelitian menunjukkan bahwa komponen proses belajar mengajar memperoleh tingkat persepsi sebesar 79\%, komponen kemampuan dosen memperoleh tingkat persepsi sebesar $82 \%$, dan komponen saranan prasarana memperoleh tingkat persepsi sebesar $80 \%$ presentase ini menunjukkan nilai kelayakan atau keberhasilan praktik daring. Secara keseluruhan dapat disimpulkan bahwa nilai persepsi mahasiswa terhadap perkuliahan praktikum dengan daring di Universitas Teknologi Yogyakarta bernilai positif dengan tingkat persepsi $80 \%$.
} 


\section{PENDAHULUAN}

Pembelajaran adalah interaksi antara guru dan peserta didik di kelas. Suyono \& Hariyanto (2016:12) menyatakan bahwa pembelajaran merupakan proses interaksi peserta didik dengan pendidik dan sumber belajar pada suatu lingkungan belajar yang meliputi guru dan siswa yang saling bertukar informasi. Proses belajar mengajar melibatkan kegiatan belajar dan mengajar untuk menentukan keberhasilan siswa dan mencapai tujuan pendidikan. Belajar merupakan proses mencari ilmu seseorang dengan pelatihan, pembelajaran untuk merubah diri sendiri.

Proses pembelajaran merupakan suatu sistem yang melibatkan berbagai komponen yang saling berkaitan dan saling berinteraksi (Pane \& Darwis Dasopang, 2017:338). Pembelajaran mempunyai manfaat memperoleh pengetahuan dan pengalaman yang bisa dikembangkan (Suyono \& Hariyanto, 2016:12).

Covid 19 (Corona Virus Disease 2019) muncul pada akhir tahun 2019 di Wuhan. Virus Covid 19 adalah virus yang penularannya sangat cepat dan sulit dikendalikan. Semua negara mengalami dampak Covid 19 dan menerapkan lockdown untuk mengantisipasi penyebaran Covid 19. Berbagai sektor lumpuh, awal mulanya adalah sektor ekonomi namun dengan semakin mengganasnya covid 19 sektor pendidikan pun ikut lumpuh dan hampir semua sekolah diberbagai negara menerapkan SWH (School From Home). Hal ini dilakukan dengan tujuan untuk mencegah penyebaran COVID-19. UNESCO mencatat sekitar 188 negara di dunia terdampak COVID-19.

PBB menyatakan salah satu sektor yang terdampak adalah dunia Pendidikan (Purwanto dkk, 2020:1). Pada sektor pendidikan, sekitar 1,5 milyar peserta didik terkena dampak COVID-19. World Health Organization (WHO) merekomendasikan untuk menghentikan sementara kegiatan-kegiatan yang akan berpotensi menimbulkan kerumunan massa. Hal ini juga diatur dalam Surat Keputusan Bersama 4 Menteri bahwa proses pembelajaran khususnya di jenjang pendidikan tinggi pada semester gasal tahun akademik 2020/2021 di semua zona wajib diselenggarakan secara daring untuk mata kuliah teori. Sementara untuk mata kuliah praktik juga sedapat mungkin tetap dilakukan secara daring. Namun, jika menyangkut kelulusan dan kompetensi mahasiswa yang tidak dapat dilaksanakan secara daring maka kegiatan tersebut dapat diselenggarakan dengan tetap mengutamakan kesehatan dan keselamatan mahasiswa, dosen dan karyawan. Pandemi Covid-19 yang mengharuskan Dosen dan mahasiswa untuk melakukan aktivitas perkuliahan dari rumah, membuat sistem pembelajaran jarak jauh dianggap sebagai solusi masalah dalam melaksanakan pembelajaran. Pendidikan jarak jauh adalah pendidikan yang perserta didiknya terpisah dari pendidik dan pembelajarannya menggunakan berbagai sumber belajar melalui teknologi komunikasi, informasi dan media lain (UU nomor 20 tahun 2003 pasal 1 ayat 15). Pendidikan jarak jauh (PJJ) adalah mengajarkan peserta didik belajar mandiri dan terpisah dari pendidik dan pembelajarannya menggunakan sumber belajar internet dan online. Karakteristik pendidikan jarak jauh antara lain: 1) Adanya keterpisahan pembelajaran yang mendekati unsur permanen antara tenaga pengajar dari perserta didik selama program pendidikan berlangsung, 2) Adanya keterpisahan antara seseorang perserta didik dengan perserta didik lainnya selama program pendidikan, 3) Adanya suatu institusi yang mengelolah progaram pendidikannya. 4) Pemanfaatan sarana komunikasi yang baik mekanis sebagai bahan belajar, 5) Penyedian sarana komunikasi dua arah sehingga perserta didik dapat mengambil inisiatif dialog dan mencari dan mengolah manfaatnya (Warsito, 2007:9-41).

Permasalahan muncul ketika harus melaksanakan pembelajaran jarak jauh, diantaranya jaringan internet, sarana prasarana, penyiapan materi pembelajaran secara online. Pembelajaran daring adalah pembelajaran 
dengan memanfaatkan teknologi informasi yaitu internet dan dipadukan dengan alat untuk menunjang aktivitas pembelajaran (Martins, 2015:77-84). Pembelajaran daring adalah pembelajaran yang dilakukan tanpa tatap muka dan menggunakan platform tertentu sehingga bisa dilakukan jarak jauh. Pembelajaran daring bertujuan untuk memberikan layanan pembelajaran dan jaringan yang lebih luas (Sofyana \& Abdul, 2019:82). Berbagai aplikasi kegiatan belajar mengajar jarak jauh antara lain, whatsapp, zoom, web blog, edmodo dan lainlain. Pembelajaran daring mempunyai tantangan dalam keahlian penggunaan teknologi informasi baik dari pendidik maupun peserta didik.

Kondisi yang tiba-tiba membuat dosen dan mahasiswa gagap melakukan pembelajaran di kelas dengan virtual meeting. Dalam pembelajaran jarak jauh ada beberapa peran yang harus diperhatikan diantaranya, 1) siswa dalam pembelajaran jarak jauh tetap memerlukan motivasi, perencanaan dan kemampuan untuk menganalisa materi, tugas dan tes secara mandiri. 2) kampus mempunyai peran sebagai kesuksesan dari sistem pembelajaran jarak jauh seperti penyediaan sarana prasarana bagi dosen pengampu untuk mengadaptasi cara mengajar dengan sistem dikelas menjadi pembelajaran berbasis teknologi.

Pembelajaran Praktik merupakan salah satu pembelajaran yang terkena dampak Covid19. Pembelajaran praktik yang capaian kompetensinya adalah meningkatkan ketrampilan dan kompetensi mahasiswa dalam menggunakan peralatan, software dan mengembangkan berbagai projek. Pembelajaran praktikum merupakan kegiatan belajar yang mempunyai tujuan supaya siswa dapat menguji dan mengaplikasikan dalam laboratorium maupun luar laboratorium (Rustaman, 2005:135). Metode praktikum adalah cara penyajian pelajaran dengan menggunakan percobaan. Dalam pelaksanaan metode ini siswa melakukan kegiatan yang mencakup pengendalian variabel, pengamatan, melibatkan pembanding atau kontrol, dan penggunaan alatalat praktikum. Dalam proses belajar mengajar dengan metode praktikum ini siswa diberi kesempatan untuk mengalami sendiri atau melakukan sendiri. Dengan melakukan praktikum siswa akan menjadi lebih yakin atas satu hal daripada hanya menerima dari guru dan buku, dapat memperkaya pengalaman, mengembangkan sikap ilmiah, dan hasil belajar akan bertahan lebih lama dalam ingatan siswa (Khairun Nisa, 2012:20-21). Metode praktikum adalah metode pembelajaran dengan cara mempraktekkan langsung untuk membuktikan suatu konsep yang sedang dipelajari (Zulfiani, Tonih Feronika, dan Kinkin Suartini, 2009:104).

Pembelajaran praktikum idelanya dilakukan secara luring, karena pandemi maka harus dilakukan secara daring. Hal ini menjadi permasalahan tersendiri mengingat infrastruktur jaringan yang belum merata di berbagai daerah. Banyak mahasiswa yang kesulitan untuk mengakses. Situasi darurat juga membuat sebagian dosen melaksanakan pembelajaran daring seadanya, hanya memberikan tugas, tidak ada interaksi, kesulitan membuat konten digital. Dari permasalahan di atas penulis mencoba mengetahui presespsi mahasiswa tentang pelaksanaan pembelajaran praktikum secara daring.

Beberapa penelitian yang telah dilakukan berkaitan dengan pembelajaran daring adalah penelitian mengenai pembelajaran daring di tengah wabah Covid-19 yang menghasilkan kesimpulan bahwa mahasiswa mempunyai fasilitas dasar untuk mengikuti pembelajaran dan pembelajaran daring menumbuhkan sikap kemandirian mahasiswa dalam belajar (Ali Sadikin, Afreni Hamidah 2020:214-224).

Penelitian lain menunjukkan hasil bahwa pembelajaran daring kurang efektif. Namum ada beberapa faktor yang mendukung yaitu ketersediaan handphone, kuota dan jaringan internet, sedangkan faktor penghambat adalah kesibukan orang tua dalam bekerja, sehingga tidak bisa mendampingi anak dalam belajar daring (Hilna Putria, Luthfi Hamdani Maula, 
dan Din Azwar Uswatun. 2020:861-872). Sedangkan penelitian Latjuba Sofyana dan Abdul Rozaq (2019:81-86) menunjukkan bahwa $69 \%$ responden menyatakan pembelajaran secara konvensional kurang efektif, minat mahasiswa dalam pembelajaran daring sekitar $89 \%$ berminat dan $78 \%$ setuju bahwa dalam penerapannya dinilai lebih efektif daripada pembelajaran konvensional.

Pembelajaran Daring Sebagai Upaya Study From Home (SFH) Selama Pandemi Covid 19 menunjukkan bahwa pembelajaran online yang dilakukan dirumah membuat siswa lebih mandiri dan berkreasi dalam belajar. Pembelajaran online merupakan salah satu hal yang mendukung penyebaran Covid 19. (Oktafia Ika Handarini. 2020:496-503).

Uji efektifitas pembelajaran berbasis daring yang dilakukan oleh Nurul Lailatul Khusniyah \& Lukam Hakim (2019:19-33). menunjukkan adanya perbedaan kemampuan mahasiswa pada teks berbahasa inggris antara sebelum dan sesudah menggunakan web blog.

Penelitian-penelitian terdahulu dilakukan pada mata kuliah teori, matakuliah praktikum berorientasi pada keterampilan dan kecakapan mahasiswa dalam pemecahan masalah dan penerapan secara langsung. Mata kuliah praktikum diselenggarakan berbasis masalah sehingga beban dosen pengampu lebih berat dibandingkan dengan dosen pengampu teori. Artikel ini bertujuan untuk mengetahui persepsi mahasiswa terhadap pelaksanaan matakuliah praktikum secara daring.

\section{METODE}

Metode yang digunakan dalam penelitian ini adalah deskriptif kuantitatif. Metode Deskriptif adalah metode yang digunakan untuk menganalisis data dengan cara mendeskripsikan atau menggambarkan data yang telah terkumpul sebagaimana adanya tanpa bermaksud membuat kesimpulan yang berlaku untuk umum atau generalisasi (Sugiyono, 2013:147). Metode kuantitatif adalah metode untuk menguji teoriteori tertentu dengan cara meneliti hubungan antar variabel. Variabel-variabel ini diukur (biasanya dengan instrumen penelitian) sehingga data yang terdiri dari angka-angka dapat dianalisis berdasarkan prosedur statistik (Sugiyono 2013:148).

Populasi penelitian ini adalah seluruh mahasiswa Universitas Teknologi Yogyakarta yang mengambil matakuliah praktik, yaitu Mata Kuliah Aplikasi Teknologi Informasi diprogram studi keteknikan. Populasi adalah gabungan dari seluruh elemen yang terbentuk peristiwa, hal, atau orang yang memiliki karakteristik serupa yang menjadi pusat perhatian peneliti, karena dipandang sebagai semesta penelitian (Augusty Ferdinand, 2011:215). Sedangkan menurut (Sujarweni dan Endrayanto, 2012:13) mengatakan bahwa, populasi adalah wilayah generalisasi yang terdiri atas objek/subjek yang mempunyai kualitas dan karakteristik tertentu yang ditetapkan oleh peneliti untuk dipelajari dan kemudian ditarik kesimpulan.

Sehingga jumlah populasi dari penelitian ini yaitu sejumlah 291 mahasiswa yang terdiri dari 98 mahasiswa program studi Pendidikan Teknologi informasi, 30 mahasiswa program studi Sistem Informasi, 29 mahasiswa Program Studi Teknik Elektro, 9 mahasiswa program studi manajemen Informatika, 15 mahasiswa program studi sistem komputer dan 110 mahasiswa program studi teknik informatika yang mengambil mata kuliah Aplikasi Teknologi Informasi.

Penentuan sampel dilakukan dengan menggunakan teknik purposive random sampling. Sampel adalah bagian dari jumlah dan karakteristik yang dimiliki oleh populasi tersebut (Sugiyono, 2013:215). Dengan demikian sampel adalah sebagian dari populasi yang karakteristiknya hendak diselidiki, dan bisa mewakili keseluruhan populasinya sehingga jumlahnya lebih sedikit dari populasi. Sampel dalam penelitian ini ditentukan dengan menggunakan rumus Slovin sebagai berikut:

$u=\frac{N}{1+N e^{2}}$ 
Dimana $\mathrm{n}$ adalah ukuran sampel yang akan dicari, $\mathrm{N}$ adalah ukuran populasi dan eee adalah margin of error yang merupakan besaran kesalahan yang diharapkan atau ditetapkan. Maka dari rumus didapatkan nilai sebagai berikut:

$$
\begin{aligned}
& n=\frac{291}{1+291 \cdot(0,05)^{2}} \\
& n=168,45
\end{aligned}
$$

Jumlah 168 kemudian didistribusikan pada masing-masing program studi dengan proporsi sebagai berikut 56 dari 98 mahasiswa yang mengambil matakuliah praktikum Aplikasi Teknologi Informasi di program studi Pendidikan Teknologi Informasi, 17 dari 30 mahasiswa yang mengambil matakuliah praktikum Aplikasi Teknologi Informasi di program studi sistem informasi, 17 dari 29 mahasiswa yang mengambil matakuliah praktikum Aplikasi Teknologi Informasi di program studi teknik elektro, 5 dari 9 mahasiswa yang mengambil matakuliah praktikum Aplikasi Teknologi Informasi di program manajemen informatika, 9 dari 15 mahasiswa yang mengambil matakuliah praktikum Aplikasi Teknologi Informasi di program studi sistem komputer dan 64 dari 110 mahasiswa yang mengambil matakuliah praktikum Aplikasi Teknologi Informasi di program studi teknik informatika.

Tabel 1. Sampel penelitian

\begin{tabular}{ccc}
\hline Nama Program Studi & $\begin{array}{c}\text { Jumlah Mahasiswa yang } \\
\text { Mengambil Matakuliah Praktik }\end{array}$ & Sampel \\
\hline Pendidikan Teknologi Informasi & 98 & 56 \\
Sistem Informasi & 30 & 17 \\
Teknik Elektro & 29 & 17 \\
Manajemen Informatika & 9 & 5 \\
Sistem Komputer & 15 & 9 \\
Teknik Informatika & 110 & 64 \\
\hline Total & 291 & 168 \\
\hline
\end{tabular}

Pengumpulan data penilaian persepsi menggunakan metode kuesioner dengan mengadaptasi kuesioner penelitian persepsi yang dilakukan oleh Hutomo Atman Maulana dan Muhammad Hamidi (2020:224-231). Tingkat persepsi mahasiswa dalam penelitian ini mengacu pada standar pengukuran yaitu: Negatif jika persentase rerata total butir komponen $\leq 40 \%$, dan positif jika persentase rerata total butir komponen $>40 \%$.

\section{HASIL DAN PEMBAHASAN}

Instrumen terdiri 12 pernyataan yang terbagi pada 3 komponen yaitu: Proses Belajar Mengajar 5 pernyataan, Kemampuan Dosen 5 pernyataan, serta Sarana dan Prasarana 2 pernyataan. Hasil dari pengumpulan data dapat dilihat pada Tabel 2. Skor maksimal pada masing-masing butir pernyataan adalah 672 yang didapat dari 4 (skor likert maksimal) dikali dengan 168 (jumlah responden).

Berdasarkan perhitungan pada keseluruhan aspek, nilai persepsi mahasiswa terhadap pembelajaran daring Universitas Teknologi Yogyakarta mendapatkan tingkat persepsi sebesar $80 \%$. Sesuai dengan standar pengukuran persepsi mahasiswa, maka dapat dinyatakan bahwa mahasiswa memiliki persepsi yang positif terhadap pembelajaran daring pada matakuliah praktik Universitas Teknologi Yogyakarta. 
Tabel 2. Hasil komponen proses belajar mengajar

\begin{tabular}{lccc}
\hline \multicolumn{1}{c}{ Komponen } & Skor Penilaian & Skor Maksimal & Persentase \\
\hline Sarana Prasarana & 2669 & 3360 & $75 \%$ \\
Kemampuan Dosen & 2741 & 3360 & $82 \%$ \\
Proses Belajar Mengajar & 1009 & 1344 & $79 \%$ \\
\hline Total & 6419 & 8064 & $80 \%$ \\
\hline
\end{tabular}

Komponen Proses Belajar Mengajar memperoleh persentase penilaian sebesar $79 \%$, yaitu 2669 dari skor maksimal 3360. Komponen Kemampuan Dosen memperoleh persentase nilai sebesar $82 \%$ yaitu 2741 dari skor maksimal 3360. Komponen Sarana Prasarana memperoleh persentase sebesar $75 \%$ yaitu skor 1009 dari skor maksimal 1344.

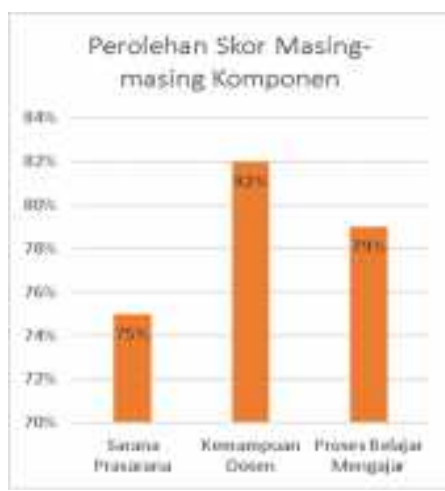

Gambar 1. Perolehan skor masingmasing komponen

Secara detail, pembahasan pada masingmasing komponen akan dijabarkan pada pembahasan berikut:

\section{Proses Belajar Mengajar}

Proses belajar mengajar ditinjau dari beberapa indikator yaitu kemudahan akses kuliah daring, ketepatan waktu kuliah daring, pemahaman teori dan keterampilan, kesesuaian materi dengan RPS serta kemudahan mengirimkan tugas/laporan praktikum.

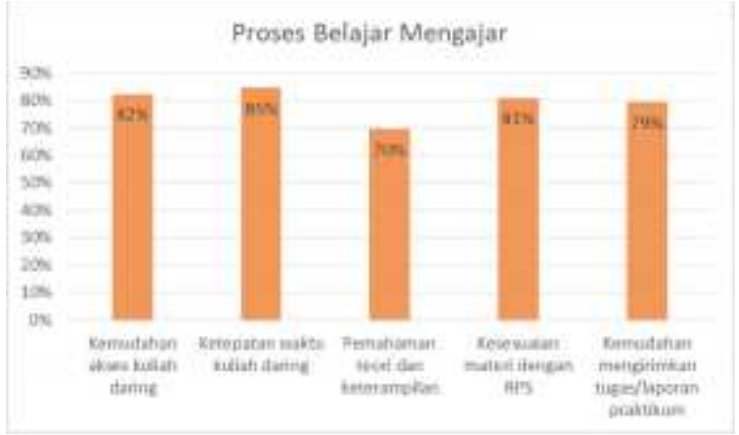

Gambar 2. Proses belajar mengajar

Tabel 3. Hasil Komponen Proses Belajar Mengajar

\begin{tabular}{|c|c|c|c|c|c|c|c|c|}
\hline Butir ke- & Indikator & $\begin{array}{c}1 \\
\text { (Sangat } \\
\text { Tidak } \\
\text { Setuju) }\end{array}$ & $\begin{array}{c}2 \\
\text { (Tidak } \\
\text { Setuju) }\end{array}$ & $\begin{array}{c}3 \\
\text { (Setuju) }\end{array}$ & $\begin{array}{c}4 \\
\text { (Sangat } \\
\text { Setuju) }\end{array}$ & $\begin{array}{l}\text { Total } \\
\text { Nilai } \\
\text { Masing- } \\
\text { masing } \\
\text { Butir }\end{array}$ & $\begin{array}{c}\text { Nilai } \\
\text { Maksimal } \\
\text { Masing- } \\
\text { masing } \\
\text { Butir }\end{array}$ & $\begin{array}{l}\text { Tingkat } \\
\text { Persepsi }\end{array}$ \\
\hline \multicolumn{9}{|c|}{ Komponen 1: Proses Belajar Mengajar } \\
\hline 1 & $\begin{array}{l}\text { Kemudahan } \\
\text { akses kuliah } \\
\text { daring }\end{array}$ & 0 & 13 & 84 & 69 & 554 & 672 & $82 \%$ \\
\hline 2 & $\begin{array}{l}\text { Ketepatan } \\
\text { waktu kuliah } \\
\text { daring }\end{array}$ & 1 & 7 & 78 & 80 & 569 & 672 & $85 \%$ \\
\hline 3 & $\begin{array}{l}\text { Pemahaman } \\
\text { teori dan }\end{array}$ & 8 & 42 & 88 & 28 & 468 & 672 & $70 \%$ \\
\hline
\end{tabular}




\begin{tabular}{cllllllll}
\hline & keterampilan & & & & & & & \\
\hline 4 & $\begin{array}{l}\text { Kesesuaian } \\
\text { materi } \\
\text { dengan RPS }\end{array}$ & 0 & 9 & 98 & 58 & 544 & 672 & $81 \%$ \\
\hline 5 & $\begin{array}{l}\text { Kemudahan } \\
\text { mengirimkan } \\
\text { tugas/laporan } \\
\text { praktikum }\end{array}$ & 3 & 21 & 83 & 60 & 534 & 672 & $79 \%$ \\
\hline
\end{tabular}
Total Komponen 1: Proses Belajar Mengajar

2669 3360 $79 \%$

Penilaian kemudahan akses kuliah daring mencapai tingkat persepsi sebanyak $82 \%$ dengan rincian skala 1 sebanyak 0 , skala 2 sebanyak 13 , skala 3 sebanyak 84 , dan skala 4 sebanyak 69 sehingga didapat total nilai sebanyak 554 dari nilai maksimal 672. Ketepatan waktu dalam kuliah daring memperoleh persentase $85 \%$ dengan rincian skala 1 sebanyak 1 , skala 2 sebanyak 7 , skala 3 sebanyak 78, skala 4 sebanyak 80 sehingga didapat total nilai sebanyak 569 dari nilai maksimal 672. Pemahaman teori dan ketrampilan memperoleh persentase sebesar $70 \%$ dengan rincian skala 1 sebanyak 8 , skala 2 sebanyak 42 , skala 3 sebanyak 88 , dan skala 4 sebanyak 28 sehingga didapat total nilai sebanyak 468 dari nilai maksimal 672. Kesesuaian materi dengan RPS memperoleh persentase sebesar $81 \%$ dengan rincian skala 1 sebanyak 0 , skala 2 sebanyak 9 , skala 3 sebanyak 98, dan skala 4 sebanyak 58 sehingga didapat total nilai sebanyak 544 dari nilai maksimal 672. Kemudahan dalam mengirimkan tugas/laporan praktikum mencapai persentase $79 \%$ dengan rincian skala 1 sebanyak 3, skala 2 sebanyak 21, skala 3 sebanyak 83, dan skala 4 sebanyak 60 sehingga didapat total nilai sebanyak 534 dari nilai maksimal 672. Total komponen proses belajar mengajar yang didapatkan mencapai $79 \%$.

\section{Kemampuan Dosen}

Aspek kemampuan dosen dilihat beberapa hal yaitu kehadiran dosen dalam perkuliahan daring, penjelasan tujuan perkuliahan, kesempatan bertanya dan diskusi, tingkat pemahaman serta tata krama.

Tabel 4. Hasil Komponen Kemampuan Dosen

\begin{tabular}{|c|c|c|c|c|c|c|c|c|}
\hline $\begin{array}{l}\text { Butir } \\
\text { ke- }\end{array}$ & Indikator & $\begin{array}{c}1 \\
\text { (Sangat } \\
\text { Tidak } \\
\text { Setuju) }\end{array}$ & $\begin{array}{c}2 \\
\text { (Tidak } \\
\text { Setuju) }\end{array}$ & $\begin{array}{c}3 \\
\text { (Setuju) }\end{array}$ & $\begin{array}{c}4 \\
\text { (Sangat } \\
\text { Setuju) }\end{array}$ & $\begin{array}{l}\text { Total } \\
\text { Nilai } \\
\text { Masing- } \\
\text { masing } \\
\text { Butir }\end{array}$ & $\begin{array}{l}\text { Nilai } \\
\text { Maksimal } \\
\text { Masing- } \\
\text { masing } \\
\text { Butir }\end{array}$ & $\begin{array}{l}\text { Tingkat } \\
\text { Persepsi }\end{array}$ \\
\hline \multicolumn{9}{|c|}{ Komponen 2: Kemampuan Dosen } \\
\hline 1 & $\begin{array}{l}\text { Kehadiran dosen } \\
\text { dalam } \\
\text { perkuliahan } \\
\text { daring }\end{array}$ & 0 & 10 & 85 & 70 & 555 & 672 & $83 \%$ \\
\hline 2 & $\begin{array}{l}\text { Penjelasan tujuan } \\
\text { perkuliahan }\end{array}$ & 1 & 3 & 89 & 72 & 562 & 672 & $84 \%$ \\
\hline 3 & $\begin{array}{l}\text { Kesempatan } \\
\text { bertanya dan } \\
\text { diskusi }\end{array}$ & 0 & 1 & 80 & 85 & 582 & 672 & $87 \%$ \\
\hline 4 & $\begin{array}{l}\text { Tingkat } \\
\text { pemahaman }\end{array}$ & 1 & 39 & 83 & 43 & 500 & 672 & $74 \%$ \\
\hline
\end{tabular}




\begin{tabular}{ccccccccc}
\hline 5 & Tata krama & 1 & 7 & 101 & 56 & 542 & 672 & $81 \%$ \\
\hline Total Komponen 2: Kemampuan Dosen & & 2741 & 3360 & $82 \%$ \\
\hline
\end{tabular}

Penilaian kehadiran dosen dalam perkuliahan daring mencapai persentase $83 \%$ dengan rincian skala 1 sebanyak 8 , skala 2 sebanyak 10 , skala 3 sebanyak 85 , skala 4 sebanyak 70 sehingga didapat total nilai sebanyak 555 dari nilai maksimal 672. Penjelasan tujuan perkuliahan mendapatkan persentase $84 \%$ dengan rincian skala 1 sebanyak 1, skala 2 sebanyak 3, skala 3 sebanyak 89 , skala 4 sebanyak 72 sehingga didapat total nilai sebanyak 562 dari nilai maksimal 672. Kesempatan bertanya dan diskusi mendapat persentase $87 \%$ dengan rincian skala 1 sebanyak 0 , skala 2 sebanyak 1 , skala 3 sebanyak 80 , skala 4 sebanyak 85 sehingga didapat total nilai sebanyak 582 dari nilai maksimal 672. Tingkat pemahaman memperoleh persentase $74 \%$ dengan rincian skala 1 sebanyak 1 , skala 2 sebanyak 39 , skala 3 sebanyak 83 , skala 4 sebanyak 43 sehingga didapat total nilai sebanyak 500 dari nilai maksimal 672. Tata krama memperoleh persentase $81 \%$ dengan rincian skala 1 sebanyak 1, skala 2 sebanyak 7 , skala 3 sebanyak 101, skala 4 sebanyak 43 sehingga didapat total nilai sebanyak 500 dari nilai maksimal 672. Total komponen kemampuan dosen yang didapatkan mencapai $82 \%$.

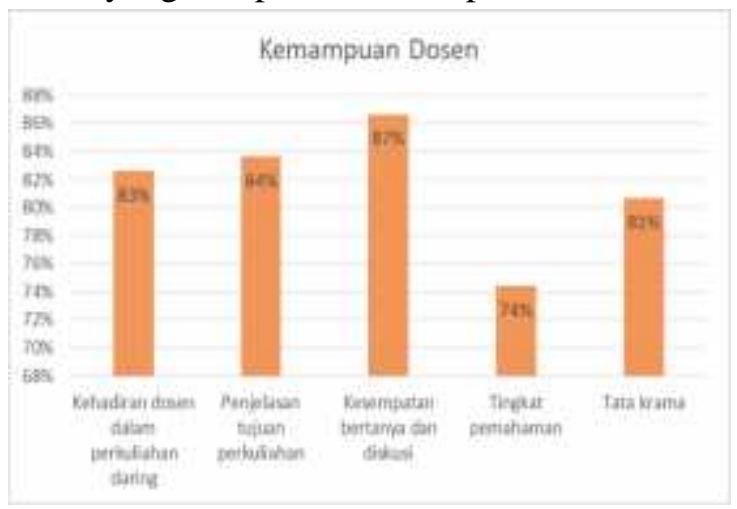

Gambar 3. Kemampuan Dosen

\section{Sarana Prasarana}

Dalam Komponen Sarana Prasana ada 2 hal yang dinilai yaitu ketersediaan pembelajaran daring dan ketersediaan perangkat praktikum.

Tabel 5. Hasil komponen kemampuan dosen

\begin{tabular}{|c|c|c|c|c|c|c|c|c|}
\hline $\begin{array}{l}\text { Butir } \\
\text { ke- }\end{array}$ & Indikator & $\begin{array}{c}1 \\
\text { (Sangat } \\
\text { Tidak } \\
\text { Setuju) }\end{array}$ & $\begin{array}{c}2 \\
\text { (Tidak } \\
\text { Setuju) }\end{array}$ & $\begin{array}{c}3 \\
\text { (Setuju) }\end{array}$ & $\begin{array}{c}4 \\
\text { (Sangat } \\
\text { Setuju) }\end{array}$ & $\begin{array}{l}\text { Total } \\
\text { Nilai } \\
\text { Masing- } \\
\text { masing } \\
\text { Butir }\end{array}$ & $\begin{array}{l}\text { Nilai } \\
\text { Maksimal } \\
\text { Masing- } \\
\text { masing } \\
\text { Butir }\end{array}$ & $\begin{array}{l}\text { Tingkat } \\
\text { Persepsi }\end{array}$ \\
\hline \multicolumn{9}{|c|}{ Komponen 3: Sarana Prasarana } \\
\hline 1 & $\begin{array}{l}\text { Ketersediaan } \\
\text { materi } \\
\text { pembelajaran } \\
\text { daring }\end{array}$ & 0 & 10 & 105 & 51 & 539 & 672 & $80 \%$ \\
\hline 2 & $\begin{array}{l}\text { Ketersediaan } \\
\text { perangkat } \\
\text { praktikum }\end{array}$ & 10 & 38 & 88 & 30 & 470 & 672 & $70 \%$ \\
\hline \multicolumn{6}{|c|}{ Total Komponen 3: Sarana Prasarana } & 1009 & 1344 & $75 \%$ \\
\hline \multicolumn{6}{|c|}{ Total } & 6419 & 8064 & $80 \%$ \\
\hline $\begin{array}{l}\text { Ke } \\
\text { daring } \\
\text { sebesar } \\
0, \text { skala } \\
\text { skala } 4\end{array}$ & $\begin{array}{l}\text { ersediaan } \\
\text { nendapatkan } \\
\% \text { dengan rin } \\
\text { sebanyak } 10 \text {, } \\
\text { ebanyak } 51 \text { s }\end{array}$ & $\begin{array}{l}\quad \text { pem } \\
\text { entase } \\
\text { skala } 1 \\
3 \text { seban } \\
\text { gga dida }\end{array}$ & $\begin{array}{l}\text { lajaran } \\
\text { nilaian } \\
\text { banyak } \\
\text { ak } 105, \\
\text { at total }\end{array}$ & $\begin{array}{l}\text { nila } \\
\text { Ket } \\
\text { pen } \\
10, \\
\text { ska }\end{array}$ & $\begin{array}{l}\text { sebanys } \\
\text { rsediaan } \\
\text { laian } 70^{\circ} \\
\text { kala } 2 \mathrm{~s} \\
4 \text { sebs }\end{array}$ & $\begin{array}{l}539 \text { da } \\
\text { perangka } \\
\text { dengan } r \\
\text { banyak } 3 \\
\text { tyak } 30\end{array}$ & $\begin{array}{l}\text { nilai mak } \\
\text { praktikum } \\
\text { acian skala } \\
\text { skala } 3 \text { se } \\
\text { ehingga di }\end{array}$ & $\begin{array}{l}\text { imal } 672 . \\
\text { mendapat } \\
\text { sebanyak } \\
\text { anyak } 88, \\
\text { apat total }\end{array}$ \\
\hline
\end{tabular}


nilai sebanyak 470 dari nilai maksimal 672 . Total skor yang didapat pada aspek sarana prasarana mencapai $75 \%$.

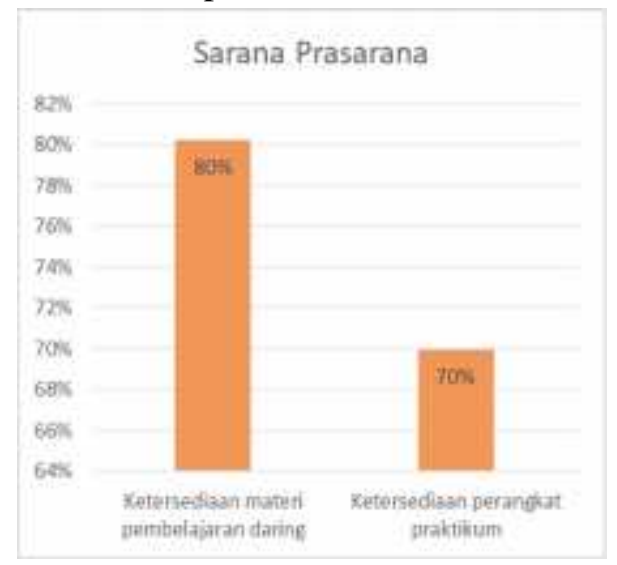

Gambar 4. Sarana Prasarana

\section{SIMPULAN}

Pembelajaran daring mampu menjadi alternatif metode pembelajaran terutama dalam pembelajaran praktikum di Universitas Teknologi Yogyakarta. Pembelajaran daring dalam praktikum mata kuliah Aplikasi Teknologi Informasi menjadi sebuah solusi yang tepat dan dapat dilaksanakan pada masa pandemi Covid 19 sehingga tidak menganggu waktu pembelajaran dan memudahkan mahasiswa serta dosen dalam pelaksanaan pembelajaran. Berdasarkan aspek proses belajar mengajar, kemampuan dosen serta sarana prasarana, proses pembelajaran daring di program studi keteknikan Universitas Teknologi Yogyakarta mendapatkan penilaian persepsi positif yaitu $80 \%$, dengan nilai masing-masing komponen yaitu proses belajar mengajar sebesar $79 \%$ yang meliputi aspek, komponen kemampuan dosen sebanyak $82 \%$ dan komponen sarana prasarana sebesar $75 \%$. Nilai ini menunjukkan keberhasilan pelaksanaan pembelajaran praktikum mata kuliah Aplikasi Teknologi Informasi dengan metode daring di program studi keteknikan Universitas Teknologi Yogyakarta. Keterbatasan mahasiswa dalam kelengkapan hardware seperti ketersediaan laptop dan peralatan praktikum menjadi kendala karena tidak semua pembelajaran praktikum bisa menggunakan simulasi. Kendala lain berkaitan dengan sarana prasarana dalam pelaksanaan pembelajaran praktikum berbasis daring ini adalah keterbatasan jaringan internet yang didaerah-daerah tertentu tidak memadai sehingga kelas yang sifatnya syncronous sering mengalami kendala. Perlu adanya berbagai alternatif teknik pengajaran untuk meningkatkan pemahaman mahasiswa, khususnya dengan metode blended learning, seperti dengan memberikan video tutorial praktik. Dengan demikian, mahasiswa bisa tetap mengakses materi saat jaringan tersedia.

\section{DAFTAR RUJUKAN}

Ali Sadikin, Afreni Hamidah. 2020. Pembelajaran Daring di Tengah Wabah Covid-19. Jurnal Ilmiah Pendidikan Biologi. 6. 02, 214-224.

Augusty Ferdinand. 2011. Metode Penelitian Manajemen Pedoman Penelitian untuk Penulisan Skripsi, Tesis, dan Disertasi Ilmu Manajemen. Semarang: Universitas Diponegoro Press.

Direktorat Jenderal Pendidikan Tinggi. 2020. Buku Panduan Penyelenggaraan Pembelajaran Semester Gasal 2020/2021 di Perguruan Tinggi. Jakarta: Direktorat Jenderal Pendidikan Tinggi Kemdikbud RI.

Hilna Putria, Luthfi Hamdani Maula, dan Din Azwar Uswatun. 2020. Penelitian berjudul Analisis Proses Pembelajaran Dalam Jaringan (DARING) Masa Pandemi COVID-19 pada Guru Sekolah Dasar. Jurnal Basicedu, 4. 4, 861 - 872.

Hutomo Atman Maulana , Muhammad Hamidi. 2020. Persepsi Mahasiswa terhadap Pembelajaran Daring pada Mata Kuliah Praktik di Pendidikan 
Vokasi. Jurnal Equilibrium: Jurnal Pendidikan. VIII. 2, 224-231.

Khairun Nisa.Penerapan Metode Praktikum Untuk Meningkatkan Hasil Belajar SiswaPada MateriFotosintesis Di Kelas VIII Mts Darul Amin Palangka Raya.skripsi.STAIN Palangka Raya, 2012.ha.20-21..

Latjuba Sofyana dan Abdul Rozaq. 2019. Penelitian berjudul Pembelajaran Daring Kombinasi Berbasis Whatsapp Pada Kelas Karyawan Prodi Teknik Informatika Universitas PGRI Madiun Jurnal Nasional Pendidikan Teknik Informatika. 8. 1, 81-86.

Martins, M. de L. (2015). How to Effectively Integrate Technology in the Foreign Language Classroom for Learning and Collaboration. Procedia - Social and Behavioral Sciences. Vol. 174, Halm. 77-84.

Nurul Lailatul Khusniyah \& Lukam Hakim. 2019. Efektifitas Pembelajaran Berbasis Daring: Sebuah Bukti Pada Pembelajaran Bahasa Inggris. Jurnal Pemikiran dan Penelitian Pendidikan. 17. 1, 19-33.

Oktafia Ika Handarini. 2020. Pembelajaran Daring Sebagai Upaya Study From Home (SFH) Selama Pandemi Covid 19. Jurnal Pendidikan Administrasi Perkantoran. 8. 3, 496-503.

Pane, A., \& Darwis Dasopang, M. 2017. Belajar Dan Pembelajaran. Jurnal
Kajian Ilmu-Ilmu Keislaman. 3. 2, 333352.

Purwanto, A., Pramono, R., Asbari, M., Santoso, P. B., Wijayanti, L. M., Hyun, C. C., \& Putri, R. S. 2020. Studi Eksploratif Dampak Pandemi COVID19 Terhadap Proses Pembelajaran Online di Sekolah Dasar. Journal of Education, Psychology and Counseling. $2.1,1-12$.

Rustaman, N. 2005. Strategi Belajar Mengajar Biologi. Malang: UM Press.

Sofyana \& Abdul. 2019. Pembelajaran Daring Kombinasi Berbasis Whatsapp Pada Kelas Karyawan Prodi Teknik Informatika Universitas PGRI Madiun. Jurnal Nasional Pendidikan Teknik Informatika. 8.1, 81-86.

Sugiyono. 2013. Metode Penelitian Kuantitatif, Kualitatif dan R\&D. Bandung: Alfabeta.CV

Sujarweni, V. W., \& Endrayanto, P. 2012. Statistika Untuk Penelitian. Yogyakarta: Graha Ilmu.

Undang-Undang nomer 20 tahun 2003. Tentang Sitem Pendidikan Nasional. Pasal 1 ayat 15.

Warsito. 2007. Peran TIK dalam Penyelenggaraan PJJ. Jurnal Teknodik. April. 20, 9-41.

Zulfiani, Tonih Feronika, dan Kinkin Suartini. 2009. Strategi Pembelajaran Sains. Jakarta: UIN Syarif Hidayatullah. 